\title{
Effects of Project Cost Overruns and Schedule Delays in Sub-Saharan Africa
}

\author{
Paul Terna Gbahabo
}

Oluseye Samuel Ajuwon

Development Finance, University of Stellenbosch Business School, Western Cape, South Africa

\begin{abstract}
This paper provides conceptual insights on the economic impact of project cost overrun and schedule delays on infrastructure procurement in developing countries with huge infrastructure deficit in Sub-Saharan Africa. Projects cost overruns and schedule delay are a major and widespread problem in infrastructure procurement the world over. It has received a lot of attention in the recent past. However, the literature reveals that extant studies on project overruns are heavily skewed towards causative factors, with little or no attention to the effects it has on the economy as a whole. The paucity of studies on the effects of project cost overrun and schedule delay will further reinforce the imperative to reacquaint policymakers and infrastructure developers, as well as project financiers with the gravity and import of the problem for infrastructural development in particular and the wider economy in general. The study undertakes an exploratory approach drawing from a wide range of secondary information and materials obtained from policy documents, study reports and peer-reviewed articles. The findings show that cost overrun and schedule delay in infrastructure procurement can have a damaging economic effect ranging from allocative inefficiency of scarce resources, further delays, contractual disputes, claims and litigation to project failure and total abandonment. The study recommends project management capacity-building for infrastructure developers, project managers as well as a number of innovative control mechanisms such as reference class forecasting, public-private partnership and computer-aided cost estimating tools including artificial neural networks, data mining, building information modelling as well as fuzzy neural inference model, genetic algorithms, and stochastic simulation to curb the menace of the problem.
\end{abstract}

Keywords: Effects of Project Cost Overruns and Schedule Delays in Sub-Saharan Africa

\section{Introduction}

The role of infrastructure in fostering economic growth and development has been established in the growth literature (Calderon, 2008). Some studies contend that the poor state of infrastructure is one of the major impediments preventing economies in Sub-Saharan Africa from leapfrogging from their current economic status into modern industrial economies (Calderon, 2008; Yepes, Pierce, and Foster 2008). For instance, Escribano, Guasch, and Pena (2008) observed that the state of infrastructure in Sub-Saharan Africa lag the global average by $30 \%$ due to deplorable condition and massive backlogs across different countries and sectors thereby leading to loss in economic growth by 2 basis points annually. Addressing this huge infrastructural deficit would require huge capital outlay- estimated to be around US\$93billion - and lengthy construction periods (Escribano, Guasch, and Pena 2008). The rapid increase in population growth in SSA and the growing demand for better utility services has made the investments in infrastructure even more imperative.

Project cost overruns and schedule delays are a widespread challenge affecting infrastructure procurement world over across time, project size and type (Flyvbjerg, Holm, and Buhl, 2003; Flyvbjerg, 2005). Flyvbjerg et. al. (2003) in their extensive study on project cost overruns and schedule delay observed over the course of 70 years that the study considered, the incidence of cost escalation had not decline and concluded that it appears no learning seemed to have taken place. Similarly, Ahiaga-Dagbui, Smith, Love and Ackermann (2015) corroborated Flyvbjerg, et. al. (2003) by submitting that in spite of the vast attention given to cost overruns and project time delay in literature and practice, not much progress appears to have been made in terms of the reliability of initial project cost estimate and predictability of final actual cost over the years. 
According to Flyvbjerg et. al. (2003), infrastructure projects are globally estimated to have $86 \%$ probability of experiencing cost escalation with average cost overrun of $45 \%$ for rail projects, $34 \%$ for bridge projects and $20 \%$ for road projects. Similarly, Love, Edwards and Irani (2012) and Odeck (2004) also contend that cost and time overruns could sometimes average $70 \%$ and $183 \%$ over the initial stipulated estimate respectively. In another related study, Ernst \&Young (2014) also reported that $64 \%$ of the infrastructures in the oil and gas industry recorded cost overruns in varying categories and in one particular instance cost overrun were as high as $59 \%$ representing cost escalation of US $\$ 500$ billion.

The high incidence and magnitude of project cost overruns and schedule delays in Sub-Saharan Africa remain unabated and only further complicates the poor infrastructural situation of the region (Flyvbjerg et. al., 2003).. A study on Nigeria transport infrastructure project reported project overrun of averaging $14 \%$ cost escalation and time schedule delay of $188 \%$ (Omoregie and Radford, 2006). Likewise in Ghana, $75 \%$ of ground water drilling projects have been reported to have exceeded budgeted cost and time (Frimpong, Oluwoye and Crawford, 2003). In Kenya, a report on range of projects under the Constituency Development Fund indicated a 48\% cost overrun and 87\% time overrun (Ngacho and Das, 2013). The study also classified the projects across different sectors and found that Agricultural market projects experienced an average of $71 \%$ project overrun while industrial estate projects witnessed project overrun of $68.3 \%$ of cost and time escalation. Project overruns has a negative effect on infrastructure procurement by raising the capital-output ratio in the sector with a concomitant negative effect on the overall economy. For instance, project overruns of cost and time has been identified as the significant factor responsible for project abandonment and high incidence of contract failure (Rwelamila, Talukhaba and Ngowi, 1999; Elinwa and Buba, 2001).

A critical review of the literature on construction cost and schedule estimates reveal that a lot of emphasis has been laid on the factors causing project cost overrun and schedule delay in Sub-Saharan Africa (Mansfield, Ugwu, and Doran,1994; Frimpong, Oluwoye and Crawford, 2003; Baloyi and Bekker, 2011) but not much has been done to highlight the consequences of project overruns and this is what this paper seeks to explore so as to exhume more seriousness on the part of project planners, contractors and policymakers on the consequences of project overruns as well as proffer policy recommendations.

The rest of the paper is organized as follows: section two reviews the extant literature on cost and schedule overruns. Section three discuss the method adopted in this study, while section four takes a brief overview of cost and schedule overruns in Sub-Saharan Africa. Sections five discuss the effects of cost overruns and schedule delay, while section six explore the control mechanisms of cost and schedule overruns. The paper concludes amid recommendations in section seven.

\section{Literature Review on Cost and Schedule Overruns}

The traditional objective of project management is the coordination of multilayered construction tasks in order to successfully procure and deliver infrastructure projects "on time, in budget and according to contract design-specification". Therefore, the iron triangular project management functions of cost, time and output performance (quality and scope) illustrated in figure 1 becomes key criteria for project control and performance evaluation (Might and Fisher, 1985; Morris and Hough, 1987; Barnes, 1988). In that sense, traditional project managers as well as engineering and procurement contractors always strive to deliver project on time and within budgets so as to avoid incidence of cost and schedule overruns in project procurement as project with overruns are often viewed as less than successful. No other study epitomized this position more than Atkinson (1999) which boldly stated that the most strategically significant measure of project failures are "time overrun", "cost overrun", and "poor quality". 
Figure 1 Project management objectives

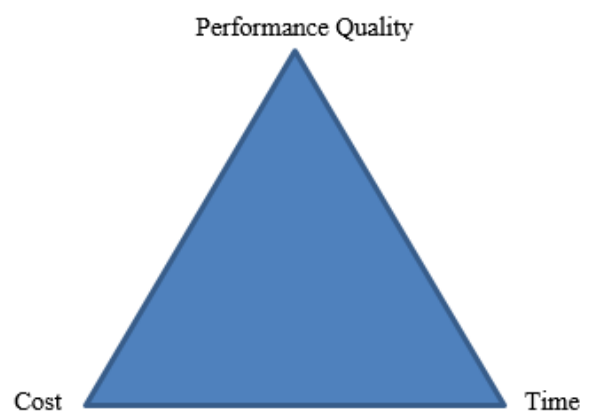

Conventionally, cost overrun is often defined as the actual turnout of costs measured as a ratio of estimated costs (Bacon and Besant-Jones, 1998; Flyvbjerg et. al.., 2003). However, cost overrun is defined by another school of thought as the difference between actual project cost at completion and budgeted estimate at project approval after adjusting for expenditures due to cost escalation (Merrow, 2011; Love, Ahiaga-Dagbui and Irani, 2016). While Schedule overrun, sometimes called schedule slippage, is defined as the margin between actual project implementation time and the estimated project implementation duration. The implementation schedule commences from the date of project approval by the main financiers and the key decision makers, to when the project comes to full commercial operation (Ansar, Flyvbjerg, Budzier and Lunn, 2013). Several empirical evidences have shown that the probability of a project experiencing overruns increases with the size and specification complexities (Baker, et. al., 1974; Flyvbjerg et. al., 2003; Standish Group, 1994). For instance, megaprojects are by their very nature chaotic and unpredictable (Standish Group, 2004; Flyvbjerg et al 2002). Similarly, special projects with high technical complexity in terms of meeting the performance specifications such as nuclear reactors, aeronautical space projects, oil and gas projects as well as thermal and hydro electrical projects are prone to high frequency and magnitude of overruns (Sovacool, Gilbert and Nugent, 2014). Project management capability and the quality of institutional environment have also been reported in some studies as critical factors in determining overruns (Baker, et. al., 1974; Flyvbjerg et. al., 2003; Cantarelli, Flyvbjerg, and Buhl, 2012). Also worthy of note, is that the use of Public-Private Partnerships in infrastructure procurement have been observed to have an inverse relationship with overruns, therefore an increase in its use would help reduce the incidence and magnitude of overruns (Blanc-Brude, Goldsmith and Välilä, 2009; Kostkaa and Anzinger, 2015; Siemiatycki, 2015)

Although several causal factors of overruns have been documented in the literature but for the purpose of this study we shall be restricting ourselves to five broad categories proposed by Baker, et. al. 1974, Flyvbjerg, et. al., 2003 and AhiagaDagbui and Smith

According to Flyvbjerg (2005) and Siemiatycki (2015), the factors influencing project cost over-runs and time slippages can be broadly classified into three categories: Technical issues, optimism bias issues, and Strategic deception and misrepresentation issues.

\section{Technical Issues}

Technical issues account for the most common explanations for project cost overruns and schedule delays. Common examples of technical glitches leading to project overruns comprise inaccurate forecasting and cost estimating techniques, insufficient data and poor judgments arising from lack of sufficient experience in project cost forecasting and estimation as well as the general inability to predicting the future (Flyvbjerg, Holm, and Buhl, 2002; Siemiatycki, 2015).

\section{Optimism bias}

The problem of estimation bias stemming from being overly optimistic about the prospect of a project in terms of cost and time is one of the major factors causing cost over-runs and schedule delays in infrastructure procurement. Flyvbjerg (2005) suggest this to be a more plausible cause of cost overruns and project time delays than the technical glitches, arguing that political and competitive pressures on projects incentivizes by project promoters and deemphasize costs and risks while 
overemphasizing project prospects. The concept optimism bias in project cost and time estimation was inspired from the seminal work of Kahneman and Tversky (1979) on decision-making under uncertainty. They stressed that most people often suffer from planning fallacy and optimism bias in that they tend to be delusional about their prospects and thus overexaggerate the outcome in an investment or project, while underestimating the cost.

In infrastructure project planning, it simply implies the tendency to overestimate the project completion time while underestimating the project costs and risks of the project. This is especially true for public sector infrastructure which has gained notoriety for large over-runs. According to Flyvbjerg (2005), over-optimism often arises from cognitive biases in the information processing mechanism of the human mind thereby leading to poor project forecasts and wrong estimates stemming from technical inefficiencies and systematic misrepresentation. Poor estimation and forecasting techniques as well as incomplete and unreliable data are main causes of biased estimate. Better understanding of the technicalities as well as social and political dimensions of infrastructure procurement could provide a reality check, thus reducing the incidence of optimism bias.

\section{Strategic Deception and Misrepresentation Issues}

Systematic deception and misrepresentation has been set forth by scholars and policymakers as one of the leading causative factors of project cost overruns and schedule slippage (Wachs, 1989; Flyvbjerg, Holm, and Buhl, 2002). Systematic deception and misrepresentation speaks to the possibility that project cost overruns and schedule delay may stem from a deliberate misrepresentation of facts by project planners and promoters with the sole intent to deceive. Actual project cost/benefit projections and time schedule are deliberately misrepresented by project planners and promoters in a bid to win the contract award over other competitors and to horridly commence construction. The notion of systematic misrepresentation as one of the factors causing project overruns can be traced to two theories; agency theory and the theory of strategic deception.

Flyvbjerg et. al. (2004) explained that in infrastructure procurement, agency problems arise when there is separation of project sponsors (ultimately tax payers) and infrastructure procurement by a chain of intermediaries at every phase of the project comprising promoters, engineers and procurement contractors, project management consultants, municipal authorities and state ministries, departments and agencies. They argued that deception and misrepresentation can occur at every interface between the principal (project sponsors) and agents (project planners, promoters and contractors, etc. ) due to number of reasons including the presence of information asymmetry, divergent self-interest, and differences in risk preferences. For instance, a desperate project contractor would want to get project approval by all means, thereby deliberately underestimate the cost of the project and exaggerate its benefits during the contract bidding process in order to make the project look attractive, while the self-interest of politicians is to rush through the project approval and commencement in time before the next election with total disregard for value for tax payers' money, etc.

Therefore, there is a strong incentive for project promoters to continuously underestimate the costs of infrastructure projects in order to make them attractive to financiers and tax payers as long as there are no punitive measures taken against such perpetrators. This can be controlled by introducing measures of accountability in infrastructure procurement whereby any party found to have deliberately deceived project sponsors and financiers is made liable for damages incurred.

Effective cost planning and forecasting is very crucial during the early stages of project life-cycle in ensuring that the project costs, quality and time schedule are within the economic limit of budgeted project expenditure. Accurate initial cost and schedule estimates are therefore very essential- as it aids project sponsors and financiers to make better informed decisions on whether or not to proceed before any shovel-on-the-ground (Hegazy, 2002; Chan, et. al., 2004). However, several studies on project performance have reported high incidence of cost and schedule overruns thus suggesting inefficiency in project cost estimation, planning and forecasting (Flyvbjerg et. al., 2003; Ahiaga-Dagbui et. al., 2015). Project overruns occur at any stage of project life cycle: during project planning and development phase, when project price and design is being negotiated; during project approval phase, while waiting for disbursement; during project construction procurement phase; during post-completion phase if the construction does not meet the standard quality (Siemiatycki, 2015). 
However, most cost overruns usually occur at the initial phase of a project where the uses of soft data (Rough order-ofmagnitude (ROM) estimates) are more prevalent. As a project progresses from the initial phase to the planning and construction phase where the use of soft data gives way to the use of hard data, the cost estimates improves in accuracy thereby reducing the range of cost overruns (Kerzner, 2013; Hegazy 2002). According to the European Commission DG XVI (1998), the basic elements that must be considered in order to ensure good project management practices as well as avoid cost overrun include: Cost control: entails ensuring that the infrastructure procurement guarantees value for money in terms of the project design and construction as well as ensuring that the actual cost of the project does not exceed the budget estimate; Time control: requires ensuring that the infrastructure procurement is executed within the stipulated schedule; Quality control: implies ensuring that the infrastructure procurement is executed within design-specifications in the contract and guarantees expected performance; Change control: entails ensuring that any necessary changes to the original engineering specification should be carried out within the official budget and must be subject to the approval of the sponsor.

Figure 2 Ranges of overruns

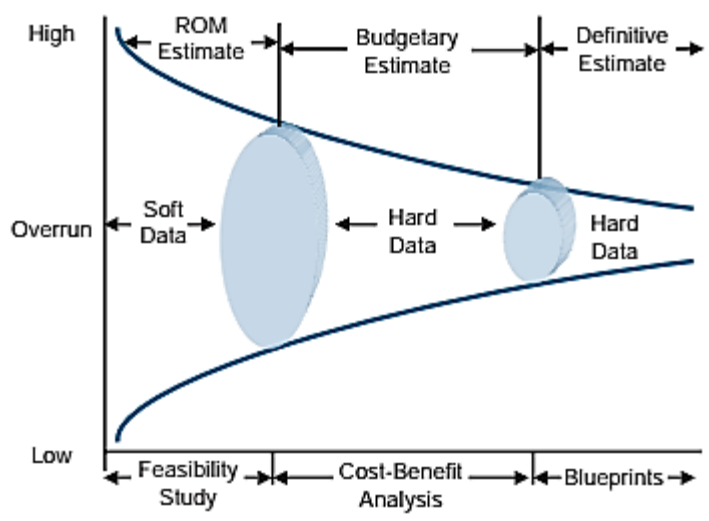

Source: Kerzner, 2013.

The seminal work of Baker, Murphy and Fisher (1974) is perhaps one of the pioneering studies on project cost and schedule overruns. The study which was sponsored by the US National Aeronautics and Space Administration investigated the determinants of project performance from a sample of 646 responses obtained from seasoned project managers and contractors. The study identified the certain critical success factors as necessary preconditions during the project planning and initiation phase: clearly expressed design-specifications; realistic project schedules; accurate cost estimates; avoidance of buy-ins; avoidance of over-optimism; favorable interface with the institutional environment; and conceptual clarity. The authors further identified some additional factors to be imperative for project success during the construction phase including, project management team's commitment and capability; the presence of on-site project manager; as well as adequate funding of construction to completion. Out of these factors, accurate initial cost estimates, realistic schedule amongst other factors as being directly related to both project success and failure. In other words, the accurate forecast of project cost and schedule amongst others or the lack thereof are necessary but insufficient factors in determining the probability of success or failure of a project. Therefore, the authors decided to expand the focus of the study to include the phenomenon of cost and schedule overruns in what is to become a pioneering inquiry on project overruns. The study also arrived at the following conclusion with respect to project overruns; cost overruns were highly correlated with the size and complexity of the project as well as the degree of difficulty in meeting project technical specifications; poor cost estimates leading to a significant percentage variance in the actual cost to budget; lack of appropriate project control systems and lack of stakeholder engagement in project decision-making; in most instances schedule difficulties and concomitant schedule overruns were identified as the primary cause of cost overruns; overruns does not imply lack of success as the study found many instances of overruns in projects that were considered successful.

\section{Methodology}


This paper is entirely an exploratory qualitative study therefore a wide range of theoretical and empirical literature as well as secondary information were obtained from policy documents, study reports from reputable organizations such as the World Bank, African Development Bank, the Standish Group, Ernest \& Young, etc. and peer reviewed articles to provide conceptual insights on the phenomenon of infrastructure project overruns in Sub-Saharan Africa. Most of the articles reviewed in this paper are empirical studies that employed data on cost and schedule overruns obtained from practical project observation or experience.

\section{Overview of Project cost and schedule delay in Sub-Saharan Africa}

The link between the quality of institutional governance and efficient and sustainable infrastructure procurement has been well documented (OED, 1996; Kenny, 2007). Studies have shown that countries with more strong institutional governance frameworks and stakeholder inclusiveness tend to experience lower risks of cost overruns and ultimately more success in project procurement than countries with weaker regulatory governance (Ansar, Flyvbjerg, Budzier and Lunn, 2013). This view has been corroborated in a World Bank's Operations Evaluation Department report (OED,1996). The study evaluated 117 World Bank sponsored infrastructure projects in sub-Saharan Africa completed between 1992 and 1997 valued at US\$4. 2 billion. The performance of the projects was considered to be below the average as 58 percent of projects outcomes were classified as satisfactory, and only 18 percent were considered sustainable.

Infrastructure project procurement performance in Sub-Saharan Africa was found to be severely constrained by weak institutions, inadequate project management capability, and poor project design as well as a high degree of uncertainty regarding the operations and maintenance of the new facilities by the host government or community.

Ansar, Flyvbjerg, Budzier and Lunn, (2013) also suggest that another reason developing countries such as those in SubSaharan Africa are more prone to a greater frequency and magnitude of project overrun is inflation and currency exchange, arguing that foreign currency exchange volatility which is so prevalent in developing countries can severely impact project cost due to the high dependence on foreign goods for project materials. Indeed, inflationary pressures and its concomitant impact on local currency devaluation is a common theme in infrastructure procurement overruns in Sub-Saharan Africa. For instance, the Tanzam Highway Rehabilitation project in Tanzania which experienced a cost overrun of $54 \%$ and a schedule overrun of 50 months attributed the cause of the overrun to a number factors including depreciation of local currency due to a spike in inflation as well as delay in cash disbursement (AfDB's OPEV, 2004).

Further compounding the issue of foreign dependence is the extensive use of foreign labour and expatriates as project consultants as well as the award of the contracts to foreign engineering procurement and construction companies due to comparative lack of experienced local project management team, thereby potentially increasing the cost of labour due to the high cost of foreign labourers. This position has been verified in Meredith (2005). The study observed that across the region there was an almost precarious dependence on foreign expertise up to a point where Nigeria Airlines was essentially managed by KLM and Nigerian Railways run by Rail India.

Flyvbjerg et. al., 2003 observed that cost underestimation is more pronounced amongst developing countries than in North America and Europe especially on transportation projects. Similarly, AfDB's OPEV (1997) reported cost underestimation and delay in funds disbursement to be the main factors attributed to 42 percent cost overruns which amounted to 10 billion CFA. F and corresponding 20 months' schedule delay on a Gabonese road maintenance project executed between 1992 and 1993.

In the same vein, the World Commission on Dams (2000) reported huge overruns in dam procurement arising from underestimation of project cost and schedule in most developing countries, with countries in Sub-Saharan Africa registering the highest underperformance. Take for instance, the case of the rehabilitation of Inga 1 and 2 dam projects in Congo DRC which recorded a huge cost overruns amounting to US \$ 1.1 billion far and above the initial estimate of US\$250 million due to mismanagement and delays in project execution. Worse still, Inga 1 and 2 not been able to operate at the estimated full capacity of $860 \mathrm{MW}$ since inception, only operating on an average less than $40 \%$ (55 MW) of the proposed capacity (International Rivers' Programme for infrastructure Development Africa Report, 2016).

Another recurring source of overrun in infrastructure procurement in Sub-Saharan Africa, especially for independent power projects is contractual disputes and arbitration (Gratwick, Ghanadan and Eberhard, 2007; Eberhard and Gratwick, 2012). The 100 MW diesel-power project procured by the Independent Power Tanzania Limited (IPTL), which was completed in 1998 but only started operations in 2002 due to delay stemming from disputes over construction cost and related capacity 
payments as well as allegations of corruption, is a good example in this regard. The cost of arbitration incurred by IPTL amounted to US $\$ 1,272$ thus contributing to total project cost overrun and further delay of 44 months, rendering the project as one of the very expensive project by the developing countries' standard due to allegations of corrupt practices between government officials and private investors.

Similarly, there was the construction of the Okpai Independent power projects in Nigeria which was also trailed with contractual disputes. However, parties were able to resolve the dispute out of court. However, the dispute did affect the payment plan as the plant did not make full payment to the national electricity company which was the off-taker, and therefore could not amortize after 5 years as originally agreed in the PPA even though the plant was producing power. Although unconnected to the dispute, the Okpai independent power project in Nigeria experience a significant budget increase by US $\$ 150$ million amid change in scope between the initial negotiations in 2001 and the plant coming on-stream (scope increase from $300 \mathrm{MW}$ to $450 \mathrm{MW}$ 2005). Factors cited for cost overrun were: vandalism as well as underestimation of the initial cost of transmission infrastructure required (Eberhard and Gratwick, 2012).

Another factor is fraudulent practices comprising non-adherence to contract conditions, kickbacks, discrepancies in contract document have also been reported as one of the causes of project cost overruns in developing countries in Sub-Saharan (Kenny, 2007). Mansfield, Ugwu and Doran (1994) noted that transportation projects in Nigeria incurred cost overruns were attributed to a number of factors which include kickbacks. Allegations of kickbacks is very rife in infrastructure projects in the sub-region and led to the spiraling out of control infrastructure project cost in the Independent Power Tanzania Limited power project (Gratwick, Ghanadan and Eberhard, 2007). US\$ 250 million were specified to have been erroneously paid to contractors due to inflated project costs and deceitful overpayment of contractors by the Petroleum Trust Fund agency officials in Nigeria between 1994 and 1999 (Tell, 2002).

\section{Effects of infrastructure project cost over-run}

This section addresses the consequences of project cost and schedule overruns on infrastructure procurement in SubSaharan Africa. The economic effects of project cost and schedule overrun are a myriad of problems ranging from the possible loss of the economic justification for the project to constituting a strain on financing capacity to secure additional foreign as well as domestic credit facility. Aibinu and Jagboro (2002) and Flyvbjerg (2005), have identified the following effects as critical consequences of infrastructure project overruns:

Pareto-inefficient allocation of resources: cost and schedule overrun often lead to waste of scarce resources as about three quarters of the infrastructure projects are funded with foreign loans or donor aid funds (Mold, 2012). According to Flyvbjerg (2005) Project cost underestimation at the planning stage arising from poor forecasting techniques often misleads decision makers to buy-in on inferior projects with high overruns and low cost-benefit thereby leading to allocative inefficiency. Cost overrun can also lead to waste when project cost spirals out of control and therefore been abandoned due to inadequate resources. This is often referred to as throwing of good money after bad project called white elephant projects. A particularly notorious example of cost overrun leading to wastage is the Nigerian Ajaokuta Steel plant which was supposed to be commissioned to start operations in September 1979 and reported worth over US $\$ 9$ billion. Over three decades have passed since the commission of Ajaokuta steel plant, yet it had still not produced any steel (The Economist, 2000).

Further delays and cost escalation: cost and schedule overrun can further complicate an overrun situation as often takes a lot of time to secure additional funding to cover overruns (Flyvbjerg, 2005). In some instances, project overruns may require a renegotiation of the contract as well as seek fresh approvals thereby leading to further cost and schedule overruns. This was particularly the case in the Gabonese road maintenance project where delay in the disbursement of funds led to further deterioration of the roads and thus necessitating renegotiation of an increase in the financing amount and terms of agreement (AfDB's OED, 1997). Similarly, Gratwick, Ghanadan and Eberhard (2007) reported that the 180 MW natural gas-fired Tanzanian independent power plant located on the Songo Songo islands which was completed 2004 incurred a cost overruns of $50 \%$ in budget due to delays and thus requiring additional debt restructuring of capacity payments. The authors reported that nearly $30 \%$ of the cost overrun was attributed to increase in debt interest charges arising from project delay which amounted to US\$100 million.

Contractual disputes and litigation: contractual disputes, litigation and arbitration are major effect of project overrun in Sub-Saharan Africa especially amongst public-private partnerships (Aibinu and Jagboro, 2002; Gratwick, Ghanadan and 
Eberhard, 2007; Kikwasi, 2012). Claims and counterclaims amongst contractual parties (usually the government agency and private investor) on whom to bear the cost of overrun as well as on the terms of the concession agreement have often led to further loss of time and revenue. Gratwick, Ghanadan and Eberhard, (2007) reported that the 100 MW Independent Power Tanzania Limited 100 MW power project that delayed for 44 months due to disputes and ligation incurred an arbitration cost of US\$1,272. The cause of the dispute was over the actual cost of the engineering and procurement construction as well as non-adherence to the contract specification by the private investor firm. Similarly, the rehabilitation of the domestic wing of the Murtala Mohammed International Airport in Lagos concession to Bi-Courtney Aviation Services Limited (BASL) ran into disputes over the actual cost incurred by the concessionaire as well as the duration of the concession. BASL claims it obtained an extension of the concession period from 12 years to 36 years to enable it recoup the over US\$230 million invested. However, this claim is being contested by the Federal Airport Authority in court as there are doubts on the concessionaire spending that much amount of money (Daily Trust, 2014).

Negative public perception: significant overruns on critical public infrastructure projects often generate negative public perception and suspicion of corruption and inefficiency thereby reducing the attractiveness of the investment (Ansar, Flyvbjerg, Budzier and Lunn, 2013). This is particularly the case with the Bujagali Hydro Power project in Uganda which attracted a lot of negative public outcry regarding the cost overruns amidst swelling allegation of corruption. The Bujagali Hydro Power project experience a budget increase from an estimated USD 430 million to USD 860 million by the end of March 2007 which social activist alleged was due to corruption and kickbacks but the project developers refutes this claim citing increase in the cost of metals by an estimated $90 \%$ over the last 5 years, increase in the cost of oil by $140 \%$ between 2000 and 2006 as well as a shortage of power generation equipment as the main cause of cost overrun (IRM, 2008)

Loss of Job and Income: Projects completed at record time and with the stipulated amount will free up resources for other usage and this will generate additional utility in the economy. The essence of any project is to create more jobs, either directly or indirectly. When projects experience overruns, it jeopardises this desire of more jobs and income. A good example is the Ajaokuta steel company that was estimated to create 6000 jobs directly and more than 1 million jobs indirectly, which never happen.

Total project abandonment: The total abandonment of infrastructure project is perhaps the worst effect of project cost and schedule overrun. Project abandonment could be temporary or for permanent duration (Aibinu and Jagboro, 2002; Murali et. al., 2007). The Nigerian Abandoned Projects Audit commission report (2011) revealed that 11, 886 federal government projects were abandoned across the country over the past 40 years due to a varied number of reasons including overruns. A particularly notorious example of abandoned project in Nigeria is the Ajaokuta Steel Company which was abandoned for over three decades after incurring over US 9 billion (Mold, 2012).

\section{Methods of mitigating and controlling project overruns}

The following cost and time overruns mitigating measures have been identified as very essential in controlling incidence of cost overrun by the European Commission DG XVI (1998):

Enhanced project management capability: the importance of appointing an effective and efficient project manager to supervise the project in a bid to mitigate project overrun in terms of cost and time cannot be overemphasized. It is the responsibility of the project manager to put in place appropriate project control and performance measures to ensure that project is completed within scheduled time and budgeted cost (European Commission DG XVI, 1998). The project managers should undertake periodic project risk assessment so as to be able to provide strategic information to the project sponsors as well as liaise with the project contractor in order to avert any situation that may lead to project overrun by reacting quickly to changing circumstances. Inefficient project risk management often lead to project over-run thereby hindering the project to meet its stipulated cost and time target.

Reference Class Forecasting: Reference class forecasting has proven to be a more accurate and successful way of controlling cost overruns especially the type arising from optimism bias (Flyvbjerg, 2003; Odeck, 2004). Reference class forecasting basically entails benchmarking new projects to a reference class of similar projects that have been recently completed in a bid to arrive at a probability distribution of likely cost estimate for the new project rather than trying to forecast offhand the specific uncertainties that might affect the project. Flyvbjerg and Cowi (2004) developed a practical guide of reference class forecasting for the UK Department for Transport. The authors developed benchmark of optimism bias uplifts by generating probability or frequency distributions of cost escalations for the different classes of project under review in 
order to arrive at a more realistic capital expenditure forecasts for each class of projects. The crux of reference class forecasting is that project cost estimators are encouraged to take an outside view in estimating project cost rather than take an inside view as studies have shown that people and organisations who took an outside view in a forecasting exercise had significantly more accurate prediction over organisations and individuals that intuitively took an inside view (Gilovich, Griffin, and Kahneman, 2002). For instance, the study suggests that optimism bias uplifts for road projects should range from $15 \%$ on the 50 th percentile rank to $32 \%$ on the 80 th percentile rank. Whereas for rail projects and other forms of urban transport, the optimism bias uplifts percentile ranges from the 50 th percentile at $40 \%$ to 80 th percentile at $57 \%$.

Computer-Aided Cost Estimating and Forecasting Models: several Computer-Aided Costs Estimating (CACE) models and tools are now available giving modern cost engineers an advantage over issues of cost overrun (Ahiaga-Dagbui and Smith, 2012). These computer aided estimators range from a simple spread sheets software to sophisticated collaborative online platforms for project construction designs, simulation models, as well as cost monitoring and control models. Some of these models include Artificial Neural Networks (Ahiaga-Dagbui and Smith, 2012), Data Mining (Ahiaga-Dagbui and Smith, 2014), Building Information Modelling (BIM) as well as 3D Cost Estimation models. Other advanced computer aided construction cost estimation methods include fuzzy neural inference model (Cheng, Tsai and Sudjono, 2009), Genetic Algorithms (Rajasekaran, Febin, and Ramasamy, 1996), Stochastic simulation (Belli, Conti, Crippa, and Turchetti, 1999) as well as Discrete - event simulation (Flood and Worley, 1995).

Risk and contingency planning: Risk and contingency planning is a very common cost overrun mitigating measure in procuring large infrastructure projects (Baccarini 2005). Contingency plans are not based on any estimation technique but rather on a "rule of thumb" calculation. They are usually an additional cost allowance on the project by a certain percentage above the base cost estimate based on the experience of the project cost engineer (European Commission DG XVI, 1998). The industry average for contingency risk allowance in many jurisdictions is a $10 \%$ figure over the gross costs. However, it is not always suitable to allocate fixed contingency allowance estimate for the entire duration of a project but rather allocated in phases as each stage comes with its specific risks and can be eliminated has they manifest. A critical review of the cost determining factors in infrastructure procurement would help to ascertain which of the costs is most likely to overrun. This in turn would enable cost engineers and project sponsors to arrive at a more correct contingency estimate.

Prequalification of contractors: Prequalification of contractors has been proven to be an effective way of controlling project overruns by screening out bidders with doubtful capability who tend to strategically misrepresent project cost in order to unduly gain contract approval (Siemiatycki, 2015). Prequalification is a process of assessing the suitability of firms to execute an engineering and procurement contract prior to commencing the actual contract bidding process by the sponsors and financiers of a construction project. The successful procurement of infrastructure projects requires that contracts approvals are only given to firms, or consortia that are suitably qualified in terms of experience, construction technology, financial and managerial competence, and can execute the project within scheduled time.

Use of Public-Private Partnerships: The OECD (2012) defines PPP as a "long term agreements between the government and a private partner whereby the private partner delivers and funds public services using a capital asset, sharing the associated risks. "Empirical evidence has shown that PPPs can be employed as a mechanism in controlling the frequency and magnitude of cost overruns (Siemiatycki, 2015; Kostka and Anzinger, 2015). For instance, Kostka and Anzinger (2015) using data from a survey of 121 large infrastructure projects spanning three sectors of the Germany economy, namely: road transport, building construction and ICT infrastructure, found that PPP projects reported significantly lower incidence and magnitude of cost overruns and project schedule delay than Non-PPP projects. The study found that PPPs in road construction projects, recorded merely $9 \%$ cost overruns as compared to $34 \%$ for Non-PPP projects. Similarly, PPPs in the building construction sector recorded cost overruns of 3\% compared to $45 \%$ of Non-PPP projects. The authors also observed that about half of total PPPs in road construction projects included in the sample reported costs under-runs.

\section{Conclusion and Recommendation}

A critical review of the literature on the concept of project overrun reveals that it is a widespread global phenomenon spanning across continents and historical divides. Project cost escalation and schedule delay continues to persist in the infrastructure projects in spite of the enormous attention given to the causative factors.

Project overruns can have adverse effect on the project procurement and on society in general ranging from escalation of cost, delay in schedule, disputes and litigation, as well as project abandonment. Efficient and effective project monitoring 
and evaluation performance has been recommended amongst other measures such as the adoption of modern computeraided cost estimating tools and class referencing as some of the best ways of mitigating against project overrun. Also, public private partnership seems to be a good method of mitigating cost and schedule overruns has documented in the literature.

\section{References}

[1] Ahiaga-Dagbui, D. D., Smith, S. D., Love, P. E. and Ackermann, F., 2015. Spotlight on construction cost overrun research: superficial, replicative and stagnated. www. openair. rgu. ac. uk

[2] Ahiaga-Dagbui, D. D. and Smith, S. D., 2012. Neural networks for modelling the final target cost of water projects. Available at www era. lib. ed. ac. uk.

[3] Ahiaga-Dagbui, D. D. and Smith, S. D., 2014. Rethinking construction cost overruns: cognition, learning and estimation. Journal of Financial Management of Property and Construction, 19(1), pp. 38-54.

[4] Aibinu, A. A. and Jagboro, G. O., 2002. The effects of construction delays on project delivery in Nigerian construction industry. International journal of project management, 20(8), pp. 593-599.

[5] Ansar, A., Flyvbjerg, B., Budzier, A. and Lunn, D., 2014. Should we build more large dams? The actual costs of hydropower megaproject development. Energy Policy, 69, pp. 43-56.

[6] Atkinson, R., 1999. Project management: cost, time and quality, two best guesses and a phenomenon, its time to accept other success criteria. International journal of project management, 17(6), pp. 337-342.

[7] Baccarini, D., 2005, July. Understanding project cost contingency: A survey. In The Queensland University of Technology Research Week International Conference.

[8] Bacon, R. W. and Besant-Jones, J. E., 1998. Estimating construction costs and schedules: experience with power generation projects in developing countries. Energy Policy, 26(4), pp. 317-333.

[9] Baker, B. N., Murphy, D. C. and Fisher, D., 1974. Determinants of project success. www. ntrs. nasa. gov

[10] Baloyi, L. and Bekker, M., 2011. Causes of construction cost and time overruns: The 2010 FIFA World Cup stadia in South Africa. Acta Structilia, 18(1), pp. 51-67.

[11] Barnes, M., 1988. Construction project management. International Journal of Project Management, 6(2), pp. 69-79.

[12] Belli, M. R., Conti, M., Crippa, P. and Turchetti, C., 1999. Artificial neural networks as approximators of stochastic processes. Neural Networks, 12(4), pp. 647-658.

[13] Berechman, J. and Wu, Q., 2006. Cost overruns risk analysis in transportation infrastructure investments. UBC P3 Project, Working Paper 2006, 5.

[14] Blanc-Brude, F., Goldsmith, H. and Välilä, T., 2009. A comparison of construction contract prices for traditionally procured roads and public-private partnerships. Review of Industrial Organization, 35(1-2), pp. $19-40$.

[15] Cantarelli, C. C., Flyvbjerg, B. and Buhl, S. L., 2012. Geographical variation in project cost performance: the Netherlands versus worldwide. Journal of Transport Geography, 24, pp. 324-331.

[16] Calderón, C. and Servén, L., 2008. Infrastructure and economic development in Sub-Saharan Africa. World Bank Policy Research Working Paper Series, Vol.

[17] Chan, A. P. and Chan, D. W., 2004. Developing a benchmark model for project construction time performance in Hong Kong. Building and Environment, 39(3), pp. 339-349.

[18] Cheng, M. Y., Tsai, H. C. and Sudjono, E., 2010. Conceptual cost estimates using evolutionary fuzzy hybrid neural network for projects in construction industry. Expert Systems with Applications, 37(6), pp. 4224-4231. 
[19] Daily Trust., 2014. MMA2: AMCON, FG should pay us N132bn damage -Bi-Courtney. Available at www. dailytrust. com. ng/daily/business/35688-mma2-amcon-fg-should-pay-us-n132bn-damage-bi-courtney.

[20] Elinwa, A. U. and Buba, A. S., 2001. Failure factors in the Nigerian construction industry. Nigerian Journal of Engineering and Management, 2(1), pp. 16-21.

[21] Eberhard, A. and Gratwick, K. N., 2012. Light inside: the experience of independent power projects in Nigeria. Infrastructure consortium for Africa.

[22] Ernest and Young., 2014. Spotlight on oil and gas megaprojects. Available at www. ey. com/Publication/vwLUAssets/EY-spotlight-on-oil-and-gas-megaprojects/. pdf

[23] Escribano, A., Guasch, J. L., Orte, M. D. and Pena, J., 2008. Investment climate assessment based on demean Olley and Pakes decompositions: methodology and application to Turkey's investment climate survey.

[24] European Commission DG XVI.,1998. Understanding and Monitoring the Cost-Determining Factors oflnfrastructureProjects. www. ec. europa. eu/regional_policy/sources/docgener/evaluation/pdf/5_full_en. pdf

[25] Flood, I. and Worley, K., 1995. An artificial neural network approach to discrete-event simulation. Artificial Intelligence for Engineering, Design, Analysis and Manufacturing, 9(01), pp. 37-49.

[26] Flyvbjerg, B., 2005. Policy and planning for large infrastructure projects: problems, causes, cures (Vol. 3781). World Bank Publications.

[27] Flyvbjerg, B., Glenting, C. and Rønnest, A. K., 2004. Procedures for dealing with optimism bias in transport planning. London: The British Department for Transport, Guidance Document.

[28] Flyvbjerg, B., Skamris Holm, M. K. and Buhl, S. L., 2004. What causes cost overrun in transport infrastructure projects?. Transport reviews, 24(1), pp. 3-18.

[29] Flyvbjerg, B., Skamris Holm, M. K. and Buhl, S. L., 2003. How common and how large are cost overruns in transport infrastructure projects?. Transport reviews, 23(1), pp. 71-88.

[30] Frimpong, Y., Oluwoye, J. and Crawford, L., 2003. Causes of delay and cost overruns in construction of groundwater projects in a developing countries; Ghana as a case study. International Journal of project management, 21(5), pp. 321-326.

[31] Gratwick, K., Ghanadan, R. and Eberhard, A., 2007. Generating Power and Controversy: Understanding Tanzania's Independent Power Projects' In Management Programme in Infrastructure Reform and Regulation.

[32] Gilovich, T., Griffin, D. and Kahneman, D., 2002. Heuristics and biases: The psychology of intuitive judgment. Cambridge university press.

[33] Hegazy, T., 2002. Computer-based construction project management. Prentice Hall.

[34] Hinze, J., Selstead, G. and Mahoney, J. P., 1992. Cost overruns on State of Washington construction contracts. Transportation Research Record, 1351, p. 87.

[35] Independent Review Mechanism. 2008. Compliance Review Report on the Bujagali Hydropower and Interconnection projects. Available www. afdb. org/fileadmin/uploads/afdb/Documents/ComplianceReview/30740990-en-bujagali-final-report-17-06-08. pdf

[36] International Rivers., 2016. Program for Infrastructure Development in Africa. www. www. partnership-africa. org/sites/default/files/PIDA-Executive-Summary-English. pdf

[37] Kahneman, D. and Tversky, A., 1979. Prospect theory: An analysis of decision under risk. Econometrica: Journal of the econometric society, pp. 263-291.

[38] Kenny, C., 2007. Infrastructure governance and corruption: where next? (Vol. 4331). World Bank Publications. 
[39] Kerzner, H. R., 2013. Project management: a systems approach to planning, scheduling, and controlling. John Wiley \& Sons.

[40] Kikwasi, G., 2013, February. Causes and effects of delays and disruptions in construction projects in Tanzania. In Australasian Journal of Construction Economics and Building-Conference Series (Vol. 1, No. 2, pp. 52-59).

[41] Kostka, G. and Anzinger, N., 2016. Large Infrastructure Projects in Germany: A Cross-sectoral Analysis. In Large Infrastructure Projects in Germany (pp. 15-38). Springer International Publishing.

[42] Love, P. E., Edwards, D. J. and Irani, Z., 2012. Moving beyond optimism bias and strategic misrepresentation: An explanation for social infrastructure project cost overruns. IEEE Transactions on Engineering Management, 59(4), pp. 560-571.

[43] Mansfield, N. R., Ugwu, O. O. and Doran, T., 1994. Causes of delay and cost overruns in Nigerian construction projects. International journal of project Management, 12(4), pp. 254-260.

[44] Meredith, M., 2005. The fate of Africa: A history of 50 years of independence. New York: Public Affairs.

[45] Merrow, E. W., 2011, January. Oil industry megaprojects: our recent track record. In Offshore Technology Conference. Offshore Technology Conference.

[46] Might, R. J. and Fischer, W. A., 1985. The role of structural factors in determining project management success. IEEE Transactions on engineering Management, (2), pp. 71-77.

[47] Mold, A., 2012. Will it all end in tears? Infrastructure spending and African development in historical perspective. Journal of International Development, 24(2), pp. 237-254.

[48] Morris, P. W. and Hough, G. H., 1987. The anatomy of major projects: A study of the reality of project management.

[49] Ngacho, C. and Das, D., 2014. A performance evaluation framework of development projects: An empirical study of Constituency Development Fund (CDF) construction projects in Kenya. International Journal of Project Management, 32(3), pp. 492-507.

[50] Omoregie, A. and Radford, D., 2006, April. Infrastructure delays and cost escalation: Causes and effects in Nigeria. In Proceeding of sixth international postgraduate research conference (pp. 79-93).

[51] Odeck, J., 2004. Cost overruns in road construction—what are their sizes and determinants?. Transport policy, 11(1), pp. 43-53.

[52] Pierce, J., Yepes, T. and Foster, V., 2008. Making Sense of Sub-Saharan Africa's Infrastructure Endowment: A Benchmarking Approach. Work. Pap, 1.

[53] Rajasekaran, S., Febin, M. F. and Ramasamy, J. V., 1996. Artificial fuzzy neural networks in civil engineering. Computers \& Structures, 61(2), pp. 291-302.

[54] Rwelamila, P. D., Talukhaba, A. A. and Ngowi, A. B., 1999. Tracing the African Project Failure Syndrome: the significance of 'ubuntu'. Engineering Construction and Architectural Management, 6(4), pp. 335-346.

[55] Sambasivan, M. and Soon, Y. W., 2007. Causes and effects of delays in Malaysian construction industry. International Journal of project management, 25(5), pp. 517-526.

[56] Siemiatycki, M., 2015. Cost Overruns on Infrastructure Projects: Patterns, Causes, and Cures. University of Toronto, IMFG Perspectives Paper, (11).

[57] Sovacool, B. K., Gilbert, A. and Nugent, D., 2014. An international comparative assessment of construction cost overruns for electricity infrastructure. Energy Research \& Social Science, 3, pp. 152-160.

[58] Standish Group., 1994. The Chaos Report. 
[59] Available at www. standishgroup. com/sample_research_files/chaos_report_1994. pdf.

[60] OECD., 2012. Public Governance of Public-Private Partnerships. Available at www.. oecd. org/governance/budgeting/PPP-Recommendation. pdf.

[61] OED (World Bank Operations Evaluation Department),. 1999. Sub-Saharan Africa: Lessons from Four Sectors. World Bank. Washington DC.

[62] OPEV (African Development Bank Operations Evaluation department)., 2004. Tanzam Highway Rehabilitation Project. www. afdb. org/afdb/Evaluation/00158061-en-tanzania-tanzam-highway. pdf.

[63] OPEV (African Development Bank Operations Evaluation department)., 1997. Gabon Road Maintenance Project. www. afdb. org/afdb/Evaluation/ 05364225-en-gabon-road-maintenance. pdf.

[64] Wachs, M., 1989. When planners lie with numbers. APA Journal. Available at www. honolulutraffic. com/Wachs_3. pdf

[65] World Commission on Dams., 200. Dams and development: a new framework for decision-making. Earthscan Publications Ltd. London. 